\title{
Behavior and Factors Affecting the PKK Group in the Role of Household Waste Management in Pasangkayu Regency, West Sulawesi
}

\author{
Herny $^{1}$, Bagyo Yanuwiadi ${ }^{2}$, Netty S. Said ${ }^{3}$ \\ \{hernypdi12019@gmail.com ${ }^{1}$ \} \\ Universitas Brawijaya, Indonesia ${ }^{1,2,3}$
}

\begin{abstract}
The problematic factor in Pasangkayu Regency is the construction and management of waste involving PKK groups. The purpose of this study was to analyze the generation and characteristics of daily household waste and factors forming the pattern of PKK group relationships in the role of managing household waste in Pasangkayu Regency, West Sulawesi. The quantitative method is carried out by direct survey of the PKK group as a waste management group. The survey was conducted using the interview method to find out the behavioral forming variables (motivation, motivation, subjective norms, selfefficacy, knowledge, and behavior). Data analysis is formulated to determine the amount and information obtained. The volume of group waste generated for 8 days based on the Prosperous III group was $58.81 \%$ anorganic and $41.21 \%$ organic, then the Prosperous II group was $57.09 \%$ anorganic and Pre-Prosperous anorganic was $39.37 \%$ and organic $60.57 \%$. The density of organic waste produced by the Prosperous III was $251.66 \mathrm{~kg} / \mathrm{m} 3$ or 0.252 tons $/ \mathrm{m} 3$, while anorganic was $1227.97 \mathrm{~kg} / \mathrm{m} 3$ or 1.228 tons $/ \mathrm{m} 3$. Prosperous II anorganic waste is $275.91 \mathrm{~kg} / \mathrm{m} 3$ or 0.275 tons $/ \mathrm{m} 3$ while organic is $1030.16 \mathrm{~kg} / \mathrm{m} 3$ or 1.03 tons $/ \mathrm{m} 3$. The Pre-Prosperity group of anorganic waste is produced $472.95 \mathrm{~kg} / \mathrm{m} 3$ or 0.473 tons $/ \mathrm{m} 3$, while organic is $753.07 \mathrm{~kg} / \mathrm{m} 3$ or 0.75 tons $/ \mathrm{m} 3$. The pattern of forming PKK group behavior in household waste management of Pasangkayu City was determined directly by the self-efficacy factor (self-confidence), while the attitudes and motivations were influenced by the level of knowledge of PKK group members and the prevailing norms in society.
\end{abstract}

Keywords: Pasangkayu Regency, PKK Group Behavior, Waste Management.

\section{Introduction}

Pasangkayu Regency is one of the cities in West Sulawesi Province that has experienced growth and development in various sectors. These developments require concrete thoughts and actions to meet the requirements of sustainable development, which is to save the environment. The orientation of urban development in Indonesia must be emphasized on the creation of a humane city (humanopolis) and an environmentally friendly city (ecopolis). The urban planning has to pay attention to the balance of urban development rate, in terms of physical and socioeconomic aspects as well as the carrying capacity of the surrounding environment, hence the harmonization of the present and future life can be realized. Serosa [1], explains the requirements to develop a sustainable city, including: 1) Harmonization between the natural environment and the urban development environment; 2) Utilization of space, energy, and 
resources while minimizing the waste; and 3) The quality of the environment must be comfortable, safe, healthy and have aspects of preservation as well as providing a clean environment in the city.

The legal foundation related to the concept of environmentally sustainable development is contained in Law Number 32 of 2009 regarding Environmental Protection and Management. Furthermore, Article 1 paragraph (2) states that environmental protection and management are systematic and integrated efforts to preserve environmental functions, prevent environmental pollution and damage which includes planning, utilization, control, maintenance, supervision, and law enforcement. An important factor that becomes a problem is the development of the environment, especially the problem of waste and its effects. Data from the World Health Organization (WHO) research results in 2016 has shown that more than $85 \%$ of the population breathe dirty air due to waste problems [2].

Theoretically, the instrument of law that regulates waste management is contained in Law Number 18 of 2008 and expected to be able to overcome the problem of waste in the urban. Likewise, Pasangkayu Regency as a research center needs to be studied to see how much the potential for waste is generated by the community through standardized methods in Indonesia. Waste management requires collaboration between the government and the community. Therefore, it is necessary to do a driving factor for 3-R-based waste management (Reduce, Reuse, and Recycle). The PKK group became an important variable to encourage waste management and based on the description above, this study conducted identification and analysis of the formation of PKK behavior patterns in managing waste sustainably, especially in Pasangkayu Regency, West Sulawesi. The objectives of the study are to analyze the generation and characteristics of daily household waste in a quantitative manner, and the factors forming patterns of PKK behavior in the role of household waste management in Pasangkayu Regency. Through this study, it can be used as a reference basis for consideration in developing strategies to increase the role of PKK groups and community groups in the management of household waste based on participation in the Pasangkayu Regency.

\section{Material and Method}

\subsection{Study Area and Data Collection}

The research was conducted in Pasangkayu Regency, West Sulawesi, Indonesia. The selection of the study area was based on consideration of the Pasangkayu Regency as the district capital and the center of urban development with the most population. Data collection was carried out by primary and secondary data including. Primary data including behavioral variables: attitudes, motivations, subjective norms, self-efficacy, knowledge, and behavior) of the PKK group and secondary data are documents from Pasangkayu government [3][4]. The collection of behavior variable data was carried out by the observation method to find out visual phenomena that exist in the study site including environmental conditions such as the amount of waste, waste problems, waste management, the completeness of facilities and infrastructure, activities carried out by PKK groups and 3-R-based communities. Other data collection was performed by the questionnaire method, which is giving several written questions to obtain information from respondents [5]. Respondents in the interview data collection were heads of agencies (Department of Sanitation and Parks, Women's Empowerment) and community groups. The collection of the waste sample was carried out for eight consecutive days in the 
purpose to show the daily fluctuation of waste generation in the source [5][6]. Determination of the number of household waste samples to be taken if the population if $\leq 106$ people can use the following formula [6]:

Note:

$$
\mathrm{P}=\mathrm{Cd} \cdot \sqrt{ } \mathrm{PS}
$$

Ps $=$ The number of population if $\leq 106$ people.

$\mathrm{Cd}=$ Coeficient $(\mathrm{Cd}=1$ if the population density is normal, $\mathrm{Cd}<1$ if the population density is rare, $\mathrm{Cd}>1$ if the population density is dense).

According to the formula, the number of samples that must be taken from each level of the community welfare (income), as follows: High income (Prosperous family III) 8 houses, Medium income (Prosperous family II) 10 houses, and Low income (Prosperous family I) 5 houses.

\subsection{Data Analysis}

The empirical model behavior analysis and influencing factors of samples for the PKK group was performed with a simple random sampling technique, which is carried out randomly without regard to strata in the population [5]. The samples were obtained and then calculated using a formula with the number of villages: ((Population of each area $\mathrm{x}$ Total) / Number of District Population). Calculation of each type of waste percentage was carried out with the following formula: (Waste component $(\%)=\mathrm{a} / 100 \mathrm{~kg} \times 100 \%$ ), with (a) is the weight of one waste component $(\mathrm{kg})$ [7]. After the weight of each waste composition was obtained, then the percentage of the weight of each waste composition was made with the formula: (Percentage of waste weight $(\%)=$ Weight of each waste type / Total weight of the waste $\mathrm{x} 100 \%)$. After the waste was separated based on its composition and the weight had been calculated, the volume of each type of waste was calculated using the following formula: (Waste density (Ds) = Weight of waste in the measuring box (a kg) / voleume of waste in the measuring box (Vs)).

Table 1. Average waste volume based on community group qualifications

\begin{tabular}{|c|c|c|c|c|c|c|}
\hline \multirow{3}{*}{ D- } & \multicolumn{6}{|c|}{ Average waste volume based on community group qualifications } \\
\hline & \multicolumn{2}{|c|}{$\begin{array}{c}\text { Prosperous III } \\
\left(\mathrm{m}^{3} / \text { day }\right)\end{array}$} & \multicolumn{2}{|c|}{$\begin{array}{c}\text { Prosperous II } \\
\left(\mathrm{m}^{3} / \text { day }\right)\end{array}$} & \multicolumn{2}{|c|}{$\begin{array}{l}\text { Pre/Prosperous I } \\
\qquad\left(\mathrm{m}^{3} / \text { day }\right)\end{array}$} \\
\hline & Anorganic & Organic & Anorganic & Organic & Anorganic & Organic \\
\hline 1 & 0.00441 & 0.00574 & 0.00568 & 0.00231 & 0.01358 & 0.00245 \\
\hline 2 & 0.00602 & 0.00144 & 0.00053 & 0.00126 & 0.00259 & 0.00644 \\
\hline 3 & 0.00329 & 0.00301 & 0.00155 & 0.00252 & 0.00368 & 0.00140 \\
\hline 4 & 0.00382 & 0.00106 & 0.00084 & 0.00077 & 0.00294 & 0.00497 \\
\hline 5 & 0.00199 & 0.00361 & 0.00036 & 0.00036 & 0.00070 & 0.00197 \\
\hline 6 & 0.00215 & 0.00056 & 0.00117 & 0.00104 & 0.00175 & 0.00252 \\
\hline 7 & 0.00221 & 0.00151 & 0.00182 & 0.00113 & 0.00042 & 0.00315 \\
\hline 8 & 0.00123 & 0.00070 & 0.00128 & 0.00056 & 0.00315 & 0.00553 \\
\hline Avg. & 0.00314 & 0.00220 & 0.00165 & 0.00124 & 0.00360 & 0.00554 \\
\hline$\%$ & $58.81 \%$ & $41.21 \%$ & $57.09 \%$ & $42.91 \%$ & $39.37 \%$ & $60.57 \%$ \\
\hline
\end{tabular}

Source: Data Analysis, 2019. 


\section{Result and Discussion}

\subsection{The Volume of Daily Waste Generation}

The volume of waste generation was calculated based on the measurement results of the number of household samples from each category of family groups, namely prosperous III, prosperous II, and pre-prosperous + prosperous I. Observed data are provided in table 1. The measurement result of household waste volume for 8 days obtained an average daily organic and anorganic waste volume of each household in the Pasangkayu Regency. Prosperous Family III produced an average volume of anorganic waste of $0.00314 \mathrm{~m}^{3} /$ household/day or $58.81 \%$ per day and organic waste of $0.0022 \mathrm{~m}^{3} /$ household/day or $41.21 \%$ per day. The prosperous family group II produced an average volume of anorganic waste of $0.00165 \mathrm{~m} 3 /$ household/day or $57.09 \%$ and organic waste of $0.00124 \mathrm{~m}^{3} /$ household/day per day or $42.91 \%$. The underprivileged + prosperous family group I produced an average volume of anorganic waste of $0.00360 \mathrm{~m}^{3} /$ household/day or $39.37 \%$ and organic waste of $0.00554 \mathrm{~m}^{3} /$ household/day or $60.57 \%$.

Based on these data, it can be concluded that the volume of waste generated every day was different based on the level of local community prosperity. The more prosperous the population of a city, the household waste produced was greater. These results are consistent with Tiwari [7] that in urban areas with high population density and more advanced socio-economic levels is directly correlated with an increase in the proportion of the generation and composition of waste production [8]. This condition will become a complex problem to be handled because the problem of waste generation is directly related to population activities and community behavior. At present, there are still many people who think that waste is not an important issue, hence that most people throw littering on roads, rivers, beaches.

\subsection{Weight of Daily Waste Generation}

Based on the measurement results, the average daily weight of anorganic and organic waste generated by each household in Pasangkayu Regency was as follows Table 2.

Table 2. Total weight of anorganic and organic waste per day

\begin{tabular}{|c|c|c|c|c|c|c|}
\hline \multirow{3}{*}{ D- } & \multicolumn{6}{|c|}{ Average waste weight based on community group qualifications } \\
\hline & \multicolumn{2}{|c|}{$\begin{array}{c}\text { Prosperous III } \\
\left(\mathrm{m}^{3} / \text { day }\right)\end{array}$} & \multicolumn{2}{|c|}{$\begin{array}{c}\text { Prosperous II } \\
\left(\mathrm{m}^{3} / \text { day }\right)\end{array}$} & \multicolumn{2}{|c|}{$\begin{array}{l}\text { Pre/Prosperous I } \\
\left(\mathrm{m}^{3} / \text { day }\right)\end{array}$} \\
\hline & Anorganic & Organic & Anorganic & Organic & Anorganic & Organic \\
\hline 1 & 0.750 & 1.47 & 1,17 & 0.98 & 1,88 & 3.7 \\
\hline 2 & 0.890 & 1.05 & 0,37 & 0.72 & 0,86 & 2.38 \\
\hline 3 & 0.320 & 2.29 & 0,41 & 1.59 & 1,26 & 1.80 \\
\hline 4 & 1.16 & 2.05 & 0,79 & 1.33 & 0,66 & 2.14 \\
\hline 5 & 0.48 & 3.07 & 0,43 & 0.62 & 0,68 & 1.42 \\
\hline 6 & 0,78 & 1.23 & 0,58 & 0.99 & 0,56 & 2.32 \\
\hline 7 & 0,66 & 1.68 & 0,80 & 0.92 & 0,48 & 1.88 \\
\hline 8 & 0,48 & 1.38 & 0,45 & 0.79 & 0,98 & 1.06 \\
\hline Avg & 0.69 & 1.78 & 0.63 & 0.99 & 0.92 & 2.09 \\
\hline$\%$ & $29.30 \%$ & $70.7 \%$ & $38.3 \%$ & $61.6 \%$ & $30.6 \%$ & $69.3 \%$ \\
\hline
\end{tabular}


Based on the result table above, the prosperous community group III produced an average of anorganic waste of $0.69 \mathrm{~kg} /$ household/ day or $29.30 \%$ per day and organic waste of 1.78 $\mathrm{kg} /$ household/ day or $70.70 \%$ per day. Based on 1,703 prosperous households III in Pasangkayu Regency, the weight of waste generated was $1,175.07 \mathrm{~kg} /$ day $(1,175$ tons/day) for anorganic waste and 3,031.34 kg/day (3,031 tons/day) for organic waste.

The prosperous community group II produced an average of anorganic waste of $0.625 \mathrm{~kg}$ $/$ household/day or $38.35 \%$ per day and organic waste of $0.993 \mathrm{~kg} /$ household $/$ day or $61.65 \%$ per day. Based on 1,999 prosperous households II in Pasangkayu Regency, the weight of waste generation was $1,249.38 \mathrm{~kg} /$ day (1,249 tons/day) for anorganic waste and 1,985,007 kg/day (1.99 tons/day) for organic waste.

The underprivileged + prosperous community group I produced an average of anorganic waste of $0.920 \mathrm{~kg} /$ household $/$ day or $30.65 \%$ per day and organic waste of $2.09 \mathrm{~kg} /$ household $/$ day or $69.35 \%$ per day. Based on 716 pre-prosperous + prosperous households I in Pasangkayu Regency, the weight of waste generation was $658.72 \mathrm{~kg}$ /day ( $0.659 \mathrm{tons} /$ day) for anorganic waste and $1495.008 \mathrm{~kg} /$ day (1,495 tons/day) for organic waste.

Dhokhikah et al [8] states that the composition of solid waste in several cities of developing countries in Asia is dominated by biodegradable organic materials (ranging from $42 \%$ - $80 \%$ ), and recyclable materials, such as paper (ranging from 3.6\% - 30\%), and plastic (ranging from $2.9 \%$ to $19.9 \%$ ) [9][10].

The potential of urban waste can be an economically and environmentally profitable business opportunity if managed properly. Daily data on organic waste can be seen in Table 3 .

Table 3. Total weight of anorganic and organic waste per day

\begin{tabular}{cccc}
\hline \multirow{2}{*}{$\begin{array}{c}\text { Observations } \\
\text { day }\end{array}$} & \multicolumn{3}{c}{ Total weight of waste based on community group qualifications } \\
\cline { 2 - 4 } & Prosperous III & Prosperous II & Pre/Prosperous I \\
\cline { 2 - 4 } & $(\mathrm{kg} /$ day $)$ & 2.15 & (kg/day) \\
\hline 1 & 2.22 & 1.09 & 5.58 \\
2 & 1.94 & 2.00 & 3.24 \\
3 & 2.61 & 2.12 & 3.06 \\
4 & 3.21 & 1.05 & 2.80 \\
5 & 3.55 & 1.57 & 2.10 \\
6 & 2.01 & 1.72 & 2.88 \\
7 & 2.34 & 1.24 & 2.36 \\
8 & 1.86 & 1.62 & 2.04 \\
\hline Average & 2.47 & & 3.01 \\
\hline
\end{tabular}

Source: Data Analysis, 2019.

Based on the result table above, the prosperous community group III with 1,703 households produced an average total waste weight of $2.47 \mathrm{~kg} /$ household/day and a total waste generation weight of 4,206.41 kg/day (4.21 tons/day). Prosperous community group II with 1.999 households produced an average total waste weight of $1.62 \mathrm{~kg} /$ household/day and a total waste generation weight of $3,234.38 \mathrm{~kg} /$ day $(3.23 \mathrm{tons} /$ day). The underprivileged + prosperous community group I with 716 households produced an average total waste weight of $3.01 \mathrm{~kg}$ /household/day and a total waste generation weight of $2,153.73 \mathrm{~kg}$ (2.15 tons/day). 


\subsection{Composition of Daily Waste in the Household}

The results of the household waste composition analysis from each family group category, namely prosperous III, prosperous II, and pre-prosperous + prosperous are shown in Table 4 as follows. Based on the measurement results, the types of the daily waste composition produced in the Pasangkayu city consist of: plastic/cork, metal/iron, textile/fabric, glass, paper, carton, and rubber/tire. Each type/composition of the waste differed based on the community group prosperity. Plastic/cork waste type was more dominant in prosperous group III with a percentage of $27.67 \%$, prosperous family II of $25.07 \%$, and disadvantaged + prosperous family I of $18.41 \%$.

Table 4. Average Weight of Each Type

\begin{tabular}{|c|c|c|c|}
\hline \multicolumn{4}{|c|}{ community groups } \\
\hline Waste Type & Prosperous III & Prosperous II & Prosperous I \\
\hline Plastic / Cork & $0.190(27.67 \%)$ & $0.156(25.07 \%)$ & $0.167(18.41 \%$ \\
\hline Metal / Iron & $0.080(10.54 \%)$ & $0.073(12.44 \%)$ & $0.146(15.08 \%$ \\
\hline $\begin{array}{l}\text { Textiles / } \\
\text { Fabrics }\end{array}$ & $0.125(16.71 \%)$ & $0.085(15.37 \%)$ & $0.172(19.54 \%$ \\
\hline Glass & $0.097(14.65 \%)$ & $0.088(12.16 \%)$ & $0.130(12.42 \%$ \\
\hline Paper & $0.099(13.93 \%)$ & $0.096(14.53 \%)$ & $0.081(9.20 \%$ \\
\hline Carton & $0.096(15.50 \%)$ & $0.112(19.13 \%)$ & $0.097(11.63 \%$ \\
\hline Rubber / Tires & $0.003(0.98 \%)$ & $0.016(1.35 \%)$ & $0.126(13.75 \%$ \\
\hline
\end{tabular}

The pattern of type diversity and composition of waste observed in Pasangkayu City showed that plastic waste $(18.41 \%-27.67 \%)$ was the most dominant. Plastic waste creates a crucial environmental problem because it takes a long time to decompose, which is 100-500 years. It is necessary to change the behavior in handling plastic waste such as changing lifestyles by using plastic materials that can be used repeatedly and reduce the use of plastic beverage packaging. The regulation needs to be made as a legal regulation by the government regarding the problem of waste in the community. However, the most important thing is to instill an understanding that each person is responsible for their waste.

Table 5. Average Volume of Each Type

\begin{tabular}{|c|c|c|c|}
\hline \multicolumn{4}{|c|}{$\begin{array}{l}\text { The average volume of anorganic waste type/composition }\left(\mathrm{m}^{3} / \text { day }\right) \\
\text { based on community groups }\end{array}$} \\
\hline Waste Type & Prosperous III & Prosperous II & Pre/Prosperous I \\
\hline Plastic/Cork & 0.000817 & 0.00038 & 0.00067 \\
\hline Metal/ Iron & 0.000321 & 0.00020 & 0.00063 \\
\hline Textiles /Fabrics & 0.000593 & 0.00017 & 0.00061 \\
\hline Glass & 0.000497 & 0.00026 & 0.00052 \\
\hline Paper & 0.000465 & 0.00027 & 0.00028 \\
\hline Carton & 0.000486 & 0.00029 & 0.00033 \\
\hline Rubbe/Tires & 0.000032 & 0.00076 & 0.00054 \\
\hline
\end{tabular}

Source: Data Analysis, 2019.

The average volume of each type of waste had the same pattern, ie the largest volume of anorganic waste was produced by the prosperous family group III and the underprivileged + 
prosperous family I, while the lowest volume of waste was produced by the prosperous family II (Table 5).

\subsection{The density of Daily Waste in the Household}

The measurement of waste density was carried out to determine the compacting factor of waste at household sources. Waste density is measured based on the weight of the waste in kilograms compared to the volume of the measured waste $\left(\mathrm{kg} / \mathrm{m}^{3}\right)$ [7].

Table 6. Daily waste density

\begin{tabular}{rcccccc}
\hline & \multicolumn{6}{c}{ Average waste density based on community group qualifications } \\
\cline { 2 - 6 } D- & \multicolumn{2}{c}{$\begin{array}{c}\text { Prosperous III } \\
\left(\mathrm{kg} / \mathrm{m}^{3}\right)\end{array}$} & \multicolumn{2}{c}{$\begin{array}{c}\text { Prosperous II } \\
\left(\mathrm{kg} / \mathrm{m}^{3}\right)\end{array}$} & $\begin{array}{c}\text { Pre/Prosperous I } \\
\left(\mathrm{kg} / \mathrm{m}^{3}\right)\end{array}$ \\
\cline { 2 - 7 } & Anorganic & Organic & Anorganic & Organic & Anorganic & Organic \\
\hline 1 & 170.07 & 256.10 & 206.06 & 424.24 & 139.44 & 1510.20 \\
2 & 147.84 & 731.71 & 704.76 & 571.43 & 332.05 & 369.57 \\
3 & 97.26 & 760.80 & 264.52 & 630.92 & 342.21 & 1285.71 \\
4 & 304.06 & 1939.45 & 940.48 & 1727.27 & 224.89 & 430.54 \\
5 & 240.60 & 851.60 & 1204.48 & 1703.30 & 971.43 & 719.35 \\
6 & 362.96 & 2196.43 & 496.15 & 955.60 & 320.00 & 920.64 \\
7 & 298.64 & 1116.28 & 439.56 & 817.79 & 1142.86 & 596.83 \\
8 & 391.84 & 1971.43 & 351.29 & 1410.71 & 311.11 & 191.68 \\
\hline Avg & 251.66 & 1227.97 & 575.91 & 1030.16 & 472.95 & 753.07 \\
\hline \multicolumn{7}{c}{ Source: Data Analysis, 2019. }
\end{tabular}

Based on the table above, prosperous family group III produced anorganic waste of 251.66 $\mathrm{kg} / \mathrm{m}^{3}$ or 0.252 tons $/ \mathrm{m}^{3}$ and organic waste of $1227.97 \mathrm{~kg} / \mathrm{m}^{3}$ or 1,228 tons $/ \mathrm{m}^{3}$. The prosperous family group II produced an anorganic waste of $275.91 \mathrm{~kg} / \mathrm{m} 3$ or 0.275 tons $/ \mathrm{m} 3$ and organic waste of $1030.16 \mathrm{~kg} / \mathrm{m}^{3}$ or 1.03 tons $/ \mathrm{m}^{3}$. The underprivileged + prosperous family group I produced anorganic waste of $472.95 \mathrm{~kg} / \mathrm{m}^{3}$ or $0.473 \mathrm{tons} / \mathrm{m}^{3}$ and organic waste of $753.07 \mathrm{~kg} / \mathrm{m}^{3}$ or 0.75 tons $/ \mathrm{m}^{3}$.

According to Damanhuri and Ganesa [9], the value of loose waste density is between 0.20 tons $/ \mathrm{m}^{3}$. The highest density of daily waste in Pasangkayu City was $0.473 \mathrm{ton} / \mathrm{m}^{3}$ for anorganic waste in the underprivileged + prosperous family group I and 1,228 tons $/ \mathrm{m}^{3}$ of organic waste in the prosperous family group III.

\subsection{Social Engineering Model of PKK Group Behavior in Household Waste Management}

The social engineering model of PKK group behavior patterns in household waste management of Pasangkayu City, West Sulawesi was obtained through 6 variables namely knowledge, subjective norms, self-efficacy, attitudes, motivation, and behavior of waste management. The theoretical model that had been built on the conceptual framework of the study will be explained by empirical data from the field, whether the good-fit model or not. 


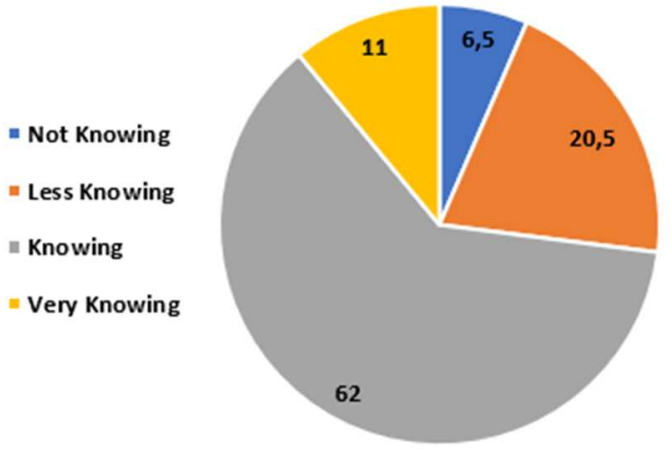

Fig 1. Knowledge Categories of Waste Management.

The frequency distribution of the specified waste management knowledge score category consists of 4 category intervals: very knowing, knowing, less knowing, and not knowing (Fig. 1). Based on 14 questions with an empirical minimum score of 22 and a maximum empirical score of 56 . Based on Fig. 1. It showed that $6.5 \%$ respondents are categorized as not knowing, $20.5 \%$ respondents are categorized as less knowing, 62\% respondents is categorized as knowing, and $11 \%$ respondents is categorized as very knowing.

The frequency distribution of self-efficacy (Fig. 2) score categories in waste management was determined by 4 category intervals: strongly agree, agree, disagree, and don't know. Based on 13 questions, the minimum score was 21, the maximum empirical score was 52 . Based on Fig. 2. It showed that 2.5\% respondents are categorized as not knowing, $27.5 \%$ respondents are categorized as disagree, $56,5 \%$ respondents are categorized as agree, and $13,5 \%$ respondents is categorized as strongly agree.

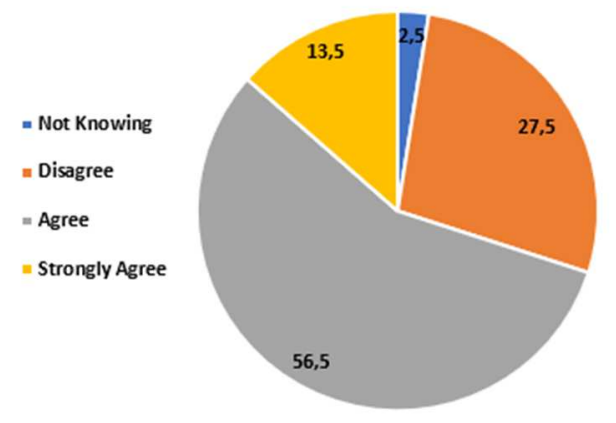

Fig. 2. Self-Efficacy Categories in Waste Management.

Frequency distribution of subjective norm (Fig. 3) score categories in waste management is determined by 4 category intervals: strongly agree, agree, disagree, and not knowing. Based on 13 questions, a minimum empirical score was 21 , a maximum empirical score was 50 . Based on Fig. 3. It showed that $1 \%$ respondents are categorized as not knowing, $7.5 \%$ respondents are categorized as disagree, $64.5 \%$ respondents are categorized as agree, and $27 \%$ respondents is categorized as strongly agree. 


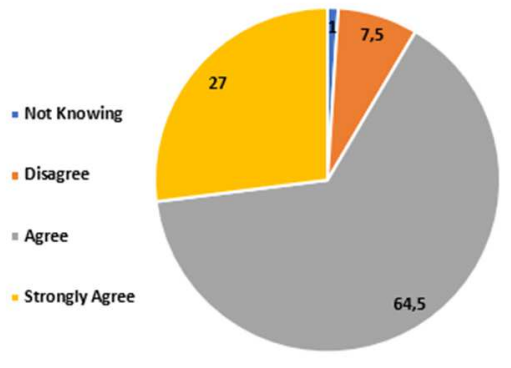

Fig. 3. Subjective Norms Categories in Waste Management.

The frequency distribution of motivation (Fig. 4.) score categories in waste management is determined by 4 category intervals: strongly agree, agree, disagree, and not knowing. Based on 13 questions with an empirical minimum score of 28 and a maximum empirical score of 52 . Based on Fig. 4. It showed that $1.5 \%$ respondents are categorized as not knowing, 5\% respondents are categorized as disagree, $68 \%$ respondents are categorized as agree, and $25.5 \%$ respondents is categorized as strongly agree.

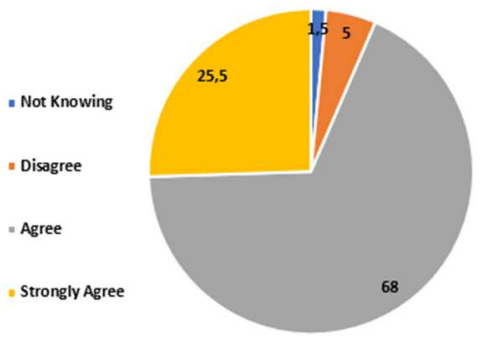

Fig. 4. Motivation Categories in Waste Management.

The frequency distribution of attitude (Fig. 5) score categories in waste management is determined by 4 category intervals, namely: very supportive, supportive, less supportive, and not knowing. Based on 13 questions with an empirical minimum score of 28 and a maximum empirical score of 48 . Based on Fig 5. It showed that $12.5 \%$ respondents are categorized as not knowing, $60.5 \%$ respondents are categorized as disagree, $26 \%$ respondents is categorized as agree, and $1 \%$ respondents is categorized as strongly agree.

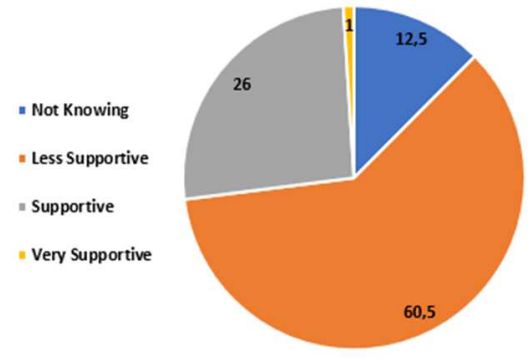

Fig. 5. Attitude Categories in Waste Management. 
Frequency distribution of behavioral (Fig. 6) score categories in waste management is determined by 4 category intervals: always doing, often doing, sometimes, and never. Based on 13 questions with an empirical minimum score of 28 and a maximum empirical score of 48 . Based on Fig 5. It showed that 4\% respondents are categorized as not knowing, $18.5 \%$ respondents are categorized as disagree, $66.5 \%$ respondents are categorized as agree, and $11 \%$ respondents is categorized as strongly agree.

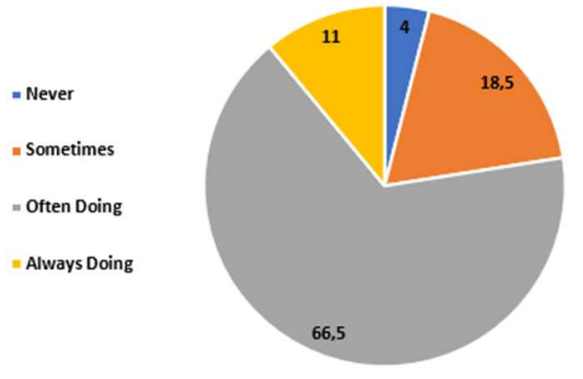

Fig. 6. Behavior Categories in Waste Management.

This section contains the results of the analysis and interpretation or discussion of the results of the analysis. Describe a structured, detailed, complete and concise explanation, so that the reader can follow the flow of analysis and thinking of researchers [5]. Part of the results study should be integrated with the results of the analysis and the results and discussion are not separated.

\section{Conclusion}

The composition of daily waste in prosperous community group III was dominated by organic waste with a proportion of $70.70 \%$ or $1.78 \mathrm{~kg} /$ day and anorganic waste with a proportion of $29.30 \%$ or $0.69 \mathrm{~kg} /$ day. The prosperous community group II was dominated by organic waste with a proportion of $61.65 \%$ or $0.993 \mathrm{~kg} /$ day and anorganic waste with a proportion of $38.35 \%$ or $0.625 \mathrm{~kg} /$ day. The pre-prosperous + prosperous community group I was dominated by organic waste with a proportion of $69,352 \%$ or $2,088 \mathrm{~kg}$ /day and anorganic waste with a proportion of $30.65 \%$ or $0.92 \mathrm{~kg} /$ day. The pattern of forming PKK group behavior in household waste management of Pasangkayu City was determined directly by the self-efficacy factor (selfconfidence), while the attitudes and motivations were influenced by the level of knowledge of PKK group members and the prevailing norms in society. However, the role of self-efficacy in the manifestation of behavior is constrained by real conditions and individual experiences, such as economic conditions, instrument readiness in waste management and government support.

\subsection{Acknowledgement}

Thank you to the PKK Group of Pasangkayu Regency for supporting this research and the entire academic community of the Doctor of Environmental Science, Postgraduate School, Brawijaya University, Malang. 


\section{References}

[1] W. Serosa, A framework for the analysis of urban sustainability: linking theory and practice, vol. 2. Jakarta: URDI, 2002.

[2] Badan Pusat Statistik, Kabupaten Mamuju Utara Dalam Angka. Badan Pusat Statistik Kabupaten Mamuju Utara, 2016.

[3] P. Grover and P. Singh, "An Analytical Study oif Effect of Family Income and Size on Per Capita Household Solid Waste Generation in Developing Countries," Am. Res. Inst. Policy Dev., vol. 3, no. 1, pp. 127-143, 2014.

[4] Sugiyono, Metode Penelitian Kuantitatif, Kualitatif dan $R \& D$. Bandung: Anggota Ikatan Penerbit Indonesia (AIPI), 2013.

[5] E. Damanhuri and T. Padmi, "Pengelolaan Sampah," Progr. Stud. Tek. Lingkung. Fak. Tek. Sipil dan Lingkungan. Inst. Teknol. Bandung, 2010.

[6] T. Setyorini, "Model Pengelolaan Sampah Berkelanjutan di Tempat Pemrosesan Akhir (TPA) Sampah Randengan Kota Mojokerto,” Universitas Brawijaya Malang, 2015.

[7] N. Tiwari, "Gender Roles in Environmental Household Waste Management: A Case Study in Palmerston North, New Zealand," 2001.

[8] Y. Dhokhikah, Y. Trihadiningrum, and S. Sunaryo, "Community participation in household solid waste reduction in Surabaya, Indonesia," Resour. Conserv. Recycl., vol. 102, pp. 153-162, 2015.

[9] E. Damanhuri and J. Ganesa, "Waste Minimization as Solution of Municipal Solid Waste Problem in Indonesia," in The 6 th ASIAN Symposium on Academic Activities for Waste Management, Padang-Indonesia, 2004, pp. 11-13.

[10] E. Damanhuri, W. Handoko, and T. Padmi, "Minicipal Solid Waste Management in Indonesia," in Municipal Solid Waste Management in Asia and the Pasific Islands, P. Agamuthu and M. Tanaka, Eds. Institut Teknologi Bandung, 2010. 